\title{
Functional properties of composite flour: a review
}

\author{
${ }^{1 *}$ Hasmadi, M., ${ }^{1}$ Noorfarahzilah, M., ${ }^{1}$ Noraidah, H., ${ }^{2}$ Zainol, M.K. and ${ }^{1}$ Jahurul, M.H.A. \\ ${ }^{1}$ Food Technology and Bioprocessing Program, Faculty of Food Science and Nutrition, Universiti Malaysia \\ Sabah, 88450 Kota Kinabalu, Sabah. \\ ${ }^{2}$ Faculty of Fisheries and Food Science, Universiti Malaysia Terengganu, 21030, Kuala Nerus, Terengganu.
}

\author{
Article history: \\ Received: 19 December 2019 \\ Received in revised form: 20 \\ April 2020 \\ Accepted: 23 April 2020 \\ Available Online: 9 May \\ 2020
}

Keywords:

Functional properties,

Composite flour,

Flour

DOI:

https://doi.org/10.26656/fr.2017.4(6).419

\begin{abstract}
Incorporation of composite flour into wheat flour for bakery goods production is expected to produce an effect in the functional properties of the blended samples. Functional properties of composite flour have been studied in most of the developing countries which used and imported a large amount of wheat flour to fulfil the increasing number of consumers as the higher demand in the development of bakery and pastry products. In this review paper, the characteristics of composite flours were reviewed to determine the suitability of the raw materials to be used in the production of food products. The functional properties such as water and oil absorption capability, foam ability, emulsion capability, least gelation concentration, and particle size distribution might indicate the capability of the composite flour before proceeding to the development of food products were reviewed. The functionality of composite flour was found to be beneficial to enhance the variety of food products with acceptable appearance, organoleptic, nutrition, and low cost to fulfil consumer demands.
\end{abstract}

\section{Introduction}

The use of composite flour to produce baked goods, if feasible, would help to lessen total dependence on imported wheat. Composite flour as an innovative flour that has attracted much attention in research as well as food product development (Hasmadi et al., 2014; Suresh et al., 2015; Gbenga-Fabusiwa et al., 2018; Jafari et al., 2018; Hasmadi et al., 2018; Nyembwe et al., 2018; Emmanuel et al., 2019). Composite flour defined as a mixture of flours obtained from tubers which rich in starch such as cassava, yam, potato, and protein-rich flour and cereals, with or without wheat flour that created to satisfy specific functional characteristics and nutrient composition (Noorfarahzilah et al., 2014). For example, wheat with sweet potatoes (Awuni et al., 2018; Edun et al., 2019), wheat and cassava (Lagnika et al., 2019; Tien et al., 2019), wheat and many legumes (Shrivastava and Chakraborty, 2018; Tufan et al., 2019), millet (Panghal et al., 2018; Wang et al., 2019) or without wheat flour (Adeola and Ohizua, 2018; Awolu, 2018; Mohammed Nour et al., 2018) and other composites (Mezgebo et al., 2018; Adeyeye, 2018; Sulieman, et al., 2019). Composite flour has better nutritional value concerning elements of minerals, vitamins, fibres and proteins than flour milled from any specific cereal alone. Shanti et al. (2005) reported that the composite flour mixture could provide a balanced nutrient. In a few years recently, composite flour became the subject of numerous studies. There has been increasing interest in replacing conventional gluten-free formulations made from refined gluten-free flour, starch, and hydrocolloids with those enriched with functional gluten-free ingredients (Traynham et al., 2007; AlvarezJubete et al., 2010).

In 1964, the FAO (Food and Agriculture Organization of the United Nations) introduced the Composite Flour Programme that aimed at the development of bakery products from locally available materials (Jisha et al., 2008). In developing countries such as Africa and other parts in the world, the used of composite flours had many benefits in a saving of hard currency and as a promotion of high yielding of native plant species. Besides that, Berghofer (2000) and Bugusu et al. (2001) also stated that the use of composite flour would promote better overall use of domestic agriculture production. According to Dendy (1993), there are two significant reasons for mixing the wheat flour with other flours; economic and nutritional. The capability, availability, and cost at the point of used are the most important things overlooked in selecting the raw material 
to produce good blend flour in terms of preference, variety, nutrition, and low cost as to fulfil consumer demands (Dendy, 1993).

Protein believed to be mostly responsible for functional properties, such as foaming, emulsification, nitrogen solubility, oil, and water absorption (Kinsella, 1979). These properties are affected by the intrinsic factors of protein, such as molecular structure and size, and many environmental factors, including the method of protein separation or production ( $\mathrm{Yu}$ et al., 2007). The low protein content and absence of gluten are considered disadvantageous for its exclusive use in food products, especially in those where the elasticity of the dough is essential for product quality. The percentage of wheat flour required to achieve a specific effect in composite flours depends heavily on the quality and quantity of wheat gluten and the nature of the product involved (Mepba et al., 2007).

The functional properties of composite flours play an essential role in the manufacturing of food products. The functional properties determine whether the blends would be useful in bakery products where hydration to improve handling desired and in ground meat, doughnuts, and pancakes where oil absorption property is of prime importance (Mepba et al., 2007). According to Kinsella (1976), functional properties are the significant physicochemical properties that are determining the complex interaction between the composition, structure, and molecular conformation. In this review paper, the functional properties of composite flour such as water absorption capacity, oil absorption capacity, particle size distribution, least gelling concentration, foaming capacity, emulsion capacity, and bulk density are reported.

\section{Water absorption capacity (WAC)}

Water absorption capacity (WAC) consists of adding water or an aqueous solution to material, followed by centrifugation and quantification of the water retained by the pelleted material in the centrifuge tube (Köhn et al., 2015). Water absorption capacity is referring to the ability of the flour or starch to hold water against gravity that can comprise of bound water, hydrodynamic water, capillary water and physically entrapped water (Moure et al., 2006). The farinographic studies showed that the blending of wheat flour with cowpea flour, germinated cowpea flour, and fermented cowpea flour was increased the water absorption capacity significantly (Masood et al., 2011). This due to the increment in protein and fibre content supplemented from wheat flour. The water absorption capacity of raw cowpea flour (2.6 g/g flour) similar to that of raw winged bean flour $(2.1 \mathrm{~g} / \mathrm{g}$ flour $)$.
Water absorption characteristics represent the ability of a product to associate with water under conditions where water is limiting, such as dough and pastes (Giami and Bekebain, 1992). The results obtained suggest that the raw and heat-treated cowpea flour would be useful in food systems such as bakery products.

Rehman et al. (2007) studied the effect of partial substitution of wheat flour (Triticum aestivum) with vetch flour (Lathyrus sativus L) at the levels of 5, 10, 15 and $20 \mathrm{~g} / 100 \mathrm{~g}$ on the physicochemical, rheological, nutritional and sensory characteristics of composite flour doughnuts. They found that the water absorption capacity of wheat flour was $58.6 \mathrm{~g} / 100 \mathrm{~g}$, which significantly $(\mathrm{P}<0.05)$ increased on increasing the amount of vetch flour. Increase in the water absorption of composite flours might be due to the increase in protein level. The flour's water absorption increases with an increase in protein content of composite flours because vetch contains more protein (26\%) than wheat (Deshpande et al., 1983). Partial substitution of wheat flour by cassava flour reduced water absorption that attributed to the lower protein content of wheat and cassava composite flours compared to that of wheat flour only (Khalil et al., 2000). Water absorption of cassava and wheat flour dough decreased by $2.5 \%$ for each $10 \%$ increase of cassava flour (Almazan, 1990). There was no drastic change in water absorption due to the addition of malt to the wheat and cassava composite flours (Khalil et al., 2000).

The presence of different hydrophilic carbohydrates (dextrin, cellulose, arabinoxylans etc), as well as different protein structures, might be responsible for variations in the water absorption capacity of the wheat flour-bran blends. Sudha et al. (2007) reported that the farinograph characteristics were shown increased in water absorption from $60.3 \%$ to $76.3 \%$ with a higher level of bran composition (0-40\%), which were in agreement with Mansour et al. (1999) that the addition of pumpkin and canola blends to wheat flour resulted in an increase in water absorption. The same observation was also reported for pigeon pea flour (138\%) (Oshodi and Ekperigin, 1989), chickpea flours (1.33-1.47 g/g) (Kaur and Singh, 2005), and sunflower flour (107\%) (Venktesh and Prakash,1993).

Incorporation of soya composite flour increased the water absorption capacity. At 20\% level of soya flour, the water absorption was $77 \%$ and at $40 \%$ level, it was 80\% (Senthil et al., 2002). Singh et al. (1996) also observed that dough containing soya flour had higher water absorption, which may be due to higher soluble protein content in the soya flour and contemporary water binding by soya flour. Therefore, the amount of water 
required for making dough increased, and the strength of the dough decreased with the increasing level of soy flour in the formulation (Senthil et al., 2002). A similar trend of increase in water absorption and decrease in stability was also observed by D'Appolonia (1977) and Silaula et al. (1989) as the percentage level of legume flour in the blend was increased.

Soybean flour recorded higher water holding capacity $(112.43 \%)$ than barinas and lara flours, as reported by Padilla et al. (1996). Rice flour and buckwheat flour had similar water absorption values as the wheat flour. Moreover, these flours developed dough, which resembles wheat flour dough in the ability to resist the deformation for a longer time. However, potato flours showed higher water absorption index and solubility than cornflour (Singh et al., 2004). Since corn flour contains lipids, contrary to potato flour, this may have been responsible for the difference in the water absorption index between corn and potato flours (Singh et al., 2004). The high-water absorption index and solubility of potato flours might be due to higher viscosity patterns and weak internal organization, resulting from negatively charged phosphate ester groups within the starch granules (Kim et al., 1996). Additionally, Giami et al. (1994) found that the water absorption capacity of raw wild mango seed flour (Irvingia gabonensis) was $3.6 \mathrm{~g} / \mathrm{g}$ flour. Since the wild mango and soy flour had different protein contents, the results obtained showed that raw wild mango flour had higher water absorption capacity ( $28.6 \mathrm{~g} / \mathrm{g}$ protein) than that of the raw soy flour $(6.6 \mathrm{~g} / \mathrm{g}$ protein).

However, the results obtained were different when the chestnut flour content is high in the blend, low values of water absorption capacity and holding are probably due to the sucrose content of chestnut (Sacchetti et al., 2004). Sucrose, in fact, as well known, has a restrictive effect on the gelatinization process (Wootton and Bamunuarachchi, 1980). The water absorption capacity of yellow and brown tigernut flour was in the range between $3.17 \%$ and $4.00 \%$, whereas germinated brown tigernut flour had the lowest water absorption value (3.97\%). The increase in water absorption capacities could be attributed to change in the quality of protein upon germination. Also, it is the capacity to hold fat globules as the number of lipophilic protein increases. It might also be an index of the ability of the protein to absorb and retain oil or water (Cheftel et al., 1985; Okezie and Bello, 1988; Obalolu and Cole, 2000)

Suresh et al. (2015) evaluate the functional properties of composite flours prepared by blending of wheat flour with rice flour, green gram flour, and potato flour in ratios of 100:0:0:0, 85:5:5:5, 70:10:10:10 and
$55: 15: 15: 15$. They found that the addition of rice, green gram, and potato flour to wheat flour affected the amount of water absorption due to due to the molecular structure of the rice, green gram, and potato starch, which inhibited water absorption. Kuntz Jr. (1971) proposed that lower WAC in flours may be due to less availability of polar amino acids in flours. The increment in WAC of composite flour may be due to an increase in the amylose leaching and solubility and loss of crystalline starch structure.

High WAC of composite flours suggests that the flours used in the formulation of some foods such as bakery products, meat products, and dairy products. The increment in the WAC correlated with an increase in the amylose leaching and solubility and loss of crystalline starch structure. The flour with high water absorption may have more hydrophilic constituents such as polysaccharides. Protein has both hydrophilic and hydrophobic nature, and therefore they can interact with water in foods (Suresh et al., 2015).

\section{Oil absorption capacity (OAC)}

Oil absorption capacity has been attributed to the physical entrapment of oil. This is important since fat acts as flavour retainer and increases the mouthfeel of food. It is an indication of the rate at which the protein binds to fat in food formulations. Oil absorption capability required in most food applications, such as in bakery products, wherein required in flavour retention and improvement of palatability (Abu et al., 2005). Soybean flour has the lowest oil absorption capacities (29.59\%) compare to lara flour and barinas flour has a higher oil absorption capacity, 35.08 and 35.70\%, respectively (Padilla et al., 1995). The non-germinated yellow tigernut flour had the highest oil absorption capacity (5.00\%). Shih and Daigle (1999) compared rice flour and wheat flour containing batters and found that rice flour resisted oil absorption better but was less effective as a thickening agent than wheat flour. The addition of pregelatinized rice flour resulted in increased oil absorption because of the porous nature of the fried product (Mohamed et al., 1998).

Another studied shows that the oil absorption capacity of the defatted flours from macadamia cultivar was more significant than those of the partially defatted flour. It has been reported by Nakai (1983) that the higher the amount of heat treatment given to a protein, the more hydrophobic the protein becomes, as a result of a higher number of hydrophobic groups exposed through the unfolding of the protein molecules. Similar observations reported for autoclaved and oven-dried cowpea flour (Giami, 1993), micronized cowpea flour 
(Mwangwela et al., 2007), roasted peanut flour (Yu et al., 2007) and low-fat soy flour (Heywood et al., 2002). Hutton and Campbell (1981), on the contrary, showed that the oil absorption capacity of soya protein decreased with increased heat. In the investigation by Maruatona et al. (2010), the higher oil absorption capacity of defatted flour from unheated marama beans reported. It is related to the fact that defatted flour from unheated marama beans contained more amino acids with nonpolar side chains than did the other flours, thereby contributing to increased oil absorption. Otherwise, it is also due to increased lipid-lipid interactions.

The presence of high-fat content in flours might have affected the oil absorption capacity (OAC) of the composite flours adversely (Chandra et al., 2014). The primary chemical component affecting OAC is a protein that is composed of both hydrophilic and hydrophobic parts. Non-polar amino acid side chains can form hydrophobic interaction with hydrocarbon chains of lipids (Jitngarmkusol et al., 2008).

\section{Particle size distribution}

An essential point for the formulation of different kinds of products for the different functionalities is the size of the particles (Abu et al., 2005). It is reported that higher amount of smaller flour particles leads to a less extensible and less fluidable dough, due to high water uptake. Generally, the hard-milling wheat, as predicted, give flours with excellent flowing properties and softmilling wheat produce flours with poor flowing properties, which may tend to flake on the smooth reduction rolls during milling of wheat (Yasui et al., 1999). Anmol (a wheat variety available in Pakistan) produced fine powdery flour, which adhered to a sieve during sifting and resulted in a low yield of the under sieve fractions (<110 um) (Rehman et al., 2007). This behaviour explained by the typical inferior quality of soft flour (Posner and Hibbs, 1997).

\section{Least gelation concentration}

The least gelation concentration (LGC), which defined as the lowest protein concentration at which gel remained in the inverted tube, was used as an index of gelation capacity. Least gelation concentration used to measure the ability of the protein to form a gel, whereby a lower least gelation concentration suggests a better gelling capacity (Abu et al., 2005). The presence of carbohydrates such as lactose, maltose, and sucrose are reported to decrease the thermodynamic affinity of the protein for an aqueous solution and magnifies the magnitude of the interaction between protein molecules, thus improving the gelling capacity (Adebowale and
Adebowale, 2008). LGC for various legume flours ranged from $12 \%$ to $14 \%$ (Maninder et al., 2007) pigeon pea flour (10\%) (Onimawo and Asugo, 2004), lupin seed flour (14\%) (Sathe et al., 1982), and high northern bean flour (10\%) (Sathe and Salunkhe, 1981). Oshodi and Ekperigin (1989) reported the least gelation concentration of $12 \%$ in pigeon pea flour. The lower the least gelation concentration, the better is the gelating ability of the protein ingredient (Akintayo et al., 1999).

The smallest gelation concentrations reported for both mucuna bean and peanut flours were 10.0\% (Del Rosario and Flores, 1981; Singh and Singh, 1991) and for cowpea flour was 16.0\% (Abbey and Ibeh, 1983). The least gelation concentrations for the raw wild mango seed and heat-treated flour samples found to be $6.0 \%$ and $8-0 \%(\mathrm{w} / \mathrm{v})$, respectively (Giami et al., 1994). They also reported that wild mango seed flour required a lower concentration for gel formation than most oilseed and legume flours. These may find useful applications in food systems such as sausage emulsions, custard type puddings, and sauces, which require thickening and gelling. Fleming et al. (1978) reported that protein concentration, especially globulin fraction, and interactions between proteins, carbohydrates, and lipids, have been responsible for the gelation capacity of legume and oilseed protein. Legume flours contain high protein and starch content, and the gelation capacity of flours influenced by real competition for water between protein gelation and starch gelatinization (Kaushal et al., 2012).

\section{Foaming capacity}

The foaming capacity measures the amount of interfacial area created by protein during foaming (Zhu et al., 2017). Foaming properties of oilseed proteins are important for the domestic market to be used in the preparation of various food products. Flours can produce foams due to surface-active proteins (Adebowale and Lawal, 2003). The foams produced by legume flours were relatively thick with low foam volume but high foam solubility. Wani et al. (2013) reported the foaming capacity of kidney bean flours at different $\mathrm{pH}(2,4,6,8$, and 10) varied from 82.1 to $132.0 \%$. Change in $\mathrm{pH}$ significantly $(\mathrm{p} \leq 0.05)$ influenced the foaming capacities of flours.

Suresh and Samsher (2013) observed the foaming capacity of different flours, that is, wheat flour, rice flour, green gram flour, and potato flour. The highest foam capacity observed for green gram flour $(24.23 \%)$ followed by wheat flour (12.92\%), potato flour $(6.84 \%)$, and lowest for rice flour (3.52\%). Green gram flour elucidated the highest foam capacity that is due high 
protein content that may cause a lowering of the surface tension at the water-air interface, thus always been due to protein, which forms a continuous, cohesive film around the air bubbles in the foam (Kaushal et al., 2012).

Kaur et al. (2011) studied the foaming capacity of field pea flour (FPF) and pigeon pea flour (PPF). They reported that the foams produced by legume flours were relatively thick with low foam volume but high foaming capacity. The foaming capacity of FPF found to be higher (39.5-42.3\%) than that of PPF (34.5-37.3\%). The results obtained in agreement with results previously reported by Mizubuti et al. (2000), but lower than the results reported by Oshodi and Ekperigin (1989) (68\%) for PPF. This may be due to the differences in protein and carbohydrate content.

Graham and Phillips (1976) observed that flexible protein molecules such as $\beta$ (beta) casein, which can rapidly reduce surface tension, gave good foamability, whereas a highly ordered globular protein molecule such as lysozyme, which is relatively difficult to surface denature gave low foamability. Mepba et al. (2007) reported that product foamability is related to the rate of decrease of the surface tension of the air/water interface caused by the absorption of protein molecules.

Germination increased the foam capacity of cowpea flour, but, like fermentation and heat treatment, decreased the foam stability compared to the raw sample (Giami, 1992) and the formability of cowpea flour is a desirable characteristic to produce several traditional cowpea-based food products in Nigeria (McWatters, 1983; McWatters and Chhinnan, 1985). The increase in foaming capacity might be due to a decrease in surface tension of the air and water interface, leading to the absorption of soluble protein molecules, thereby permitting hydrophobic interactions (Chinma et al., 2009). The foaming capacity of a food material depends on the surface-active properties of its protein (Sathe et al., 1982; Udensi and Okoronkwo, 2006). Lin et al. (1974) stated that foam stability related to the amount of native protein. The native protein showed higher foam stability than denatured protein (Yasumatsu et al., 1972).

Improved foaming properties with increasing concentration of flour have reported for glandless cottonseed flour (Cherry and Mc Watters, 1981). Foamability generally reaches a maximum value at a point as the concentration of protein increases (Adebowale and Lawal, 2004). This development enhanced foam stability. An increase in protein concentration facilitated enhanced protein-protein interaction at the air-water interface and this promoted the formation of a highly viscoelastic multiplayer film that offers resistance to the coalescence of bubbles
(Adebowale and Lawal, 2004).

\section{Emulsion capacity}

Fat emulsion capacity is the extent to which the dietary protein will would dietary oil into fine particles. It directly measures the extent to which the dietary protein will mix oil (Abulude et al., 2013). The emulsion is a two-phase system, whereby protein surface activity significantly influenced its formation (Moure et al., 2006). Food emulsions are thermodynamically unstable mixtures of immiscible liquids between water and oil (Yu et al., 2007). Ahn et al. (2005) reported that the addition of $20 \%$ soy flour to the wheat produced a significant positive effect on the emulsifying activity of the samples. However, the addition of $5 \%$ of pea or soybean protein isolates to rice flour hardly modified the emulsifying activity of rice flour dough (Marco and Rosell, 2008). Based on the report by Rosell and Marco (2008), these differences may be attributed to the different hydration of the composite blends, since water acts as a plasticizer defining the functional properties of the dough. Singh and Singh (1991) reported that the emulsion capacity of peanut flour was reduced by $26.5 \%$ as a result of boiling. An emulsion prepared from raw wild mango seed flour was more stable than that prepared from heat-treated flour, whereas heat-treatment reduced the emulsion capacity of the flour by $16.7 \%$ (Giami et al., 1994).

Adebowale and Lawal (2004) reported that the emulsion stability of mucana bean flour and jack bean flour reduced as the concentration of flour in the solution increased. However, emulsifying stability of Bambara groundnut flour; increased progressively as concentration increased until it began to decline with increasing flour concentration from $6 \% \mathrm{w} / \mathrm{v}$ upward. Sathe et al. (1981) have reported such concentrationdependent emulsifying properties. In their report, the emulsion capacity of winged bean protein reduced as the concentration of protein in solution increased. The result is also in agreement with those of Lin et al. (1974) on the emulsifying properties of sunflower and soybean flours and protein concentrates. Hailing and Walstra (1981) states that the initial increase in emulsion stability of Bambara groundnut flour with increasing concentration up to $6 \% \mathrm{w} / \mathrm{v}$ could be explained based on the increase in rigidity of interfacial lamella.

Furthermore, the increasing emulsion activity, emulsion stability, and fat binding during processing are primary functional properties of the protein in such foods as communities' meat products, salad dressings, frozen desserts, and mayonnaise (Mepba et al., 2007). Lin et al. (1974) reported the emulsion capacities of wheat flour, 
soy flour, sunflower flour, and protein concentrates and isolates from soy and sunflower flours to be in the range of 10.1 to $25.6 \%$ except for sunflower.

\section{Bulk density}

Bulk density is a measure of the heaviness of a flour sample (Oladele and Aina, 2007). The bulk density of flour used to determine its packaging requirements. It is depending on the particle size and moisture content of flours. Bulk density of composite flour increased with an increase in the incorporation of different flours with wheat flour. The high bulk density of flour suggests their suitability for use in food preparations (liquids, semisolids or solids). In contrast, low bulk density would be an advantage in the formulation of weaning foods (Akapata and Akubor, 1999). Du et al. (2014) investigated bulk density for whole flours from pinto bean, lima bean, red kidney bean, black bean, navy bean, small red bean, black eye bean, mung bean, lentil, and chickpea. They reported that the bulk density for legume flours varied from $0.543 \mathrm{~g} / \mathrm{mL}$ to $0.816 \mathrm{~g} / \mathrm{mL}$, where the highest and the lowest values obtained from lentil flour and black bean flour, respectively. The results obtained are in agreement with the results reported by Kaur and

Table 1. Bulk density of different source of flour

\begin{tabular}{ll}
\hline \multicolumn{1}{c}{ Type of flour } & Bulk density \\
\hline Wheat $^{\wedge}$ & $0.762 \pm 0.000$ \\
Buckwheat $^{++}$ & $0.810 \pm 0.030$ \\
Taro* $^{*}$ & $0.689 \pm 0.028$ \\
Potato* $^{*}$ & $0.998 \pm 0.016$ \\
Soya bean* $^{*}$ & $0.539 \pm 0.022$ \\
Corn* $^{*}$ & $0.585 \pm 0.020$ \\
Pinto bean $^{+}$ & $0.680 \pm 0.000$ \\
Lima bean $^{+}$ & $0.782 \pm 0.000$ \\
Red kidney bean $^{+}$ & $0.679 \pm 0.000$ \\
Black bean $^{+}$ & $0.543 \pm 0.010$ \\
Navy bean $^{+}$ & $0.690 \pm 0.010$ \\
Small red bean $^{+}$ & $0.683 \pm 0.000$ \\
Black eye bean $^{+}$ & $0.764 \pm 0.010$ \\
Mung bean $^{+}$ & $0.798 \pm 0.010$ \\
Lentil $^{+}$ & $0.816 \pm 0.010$ \\
Chickpea $^{+}$ & $0.573 \pm 0.000$ \\
Rice** $^{* *}$ Pigeon pea** $^{* *}$ French yellow kidney bean $^{\#}$ & $0.648 \pm 0.832$ \\
Contender kidney bean $^{\#}$ & $0.480 \pm 0.010$ \\
Master kidney bean $^{\#}$ & $0.850 \pm 0.010$ \\
Local red kidney bean $^{\#}$ & $0.840 \pm 0.010$ \\
\hline
\end{tabular}

${ }^{\wedge}$ Suresh et al. (2015), *Kaur et al. (2011), ${ }^{+} \mathrm{Du}$ et al. (2014), ${ }^{\#}$ Wani et al. (2013), **Kaushal et al. (2012), ${ }^{++}$Baljeet et al. (2010).
Singh (2005), where they reported the bulk densities of different chickpea cultivars to range from $0.536 \mathrm{~g} / \mathrm{mL}$ to $0.571 \mathrm{~g} / \mathrm{mL}$. According to Milán-Carrillo et al. (2000), the bulk density of legume flour plays an essential role in weaning food formulation, that is, reducing the bulk density of the flour is probably helpful to the formulation of weaning foods. The bulk density is a reflection of the load the sample can carry if allowed to rest directly on one another. The lower the bulk density value, the higher the amount of four particles that can stay together and thus increasing the energy content that could be derivable from such diets (Ikpeme-Emmanuel et al., 2009). Table 1 shows the bulk density of the selected flour found in the literature. Kaur et al. (2011) reported the bulk density of different flours (potato, taro, corn, and soy) varied from 0.539 to $0.998 \mathrm{~g} / \mathrm{mL}$, the highest for potato and the lowest for soya flour observed (Potato $>$ Taro $>$ Corn $>$ Soya).

\section{Conclusion}

Composite flours have been used extensively and successfully in the production of food products. The functional properties of composite flour are an essential parameter to produce various food products that are good quality in terms of appearance, organoleptic, and acceptance from consumers. The blending of wheat flour with other types of powders showed a significant effect on the functional properties of the flour blends as well as their finished products. These investigations inferred that composite flour showed positive and negative effects, and it is useful for enhancing quality in the development of food production. Most of the researches intensify the desired functional properties to improve composite flour to meet higher requirements. Moreover, composite flour probably acts as a product that gave the potential source of locally agriculture products to be usefulness in the future.

\section{Conflict of interest}

The authors declare no conflicts of interest.

\section{Acknowledgments}

The authors acknowledge the financial supported by the Higher Educational Ministry of Malaysia (ERGS0003-STWN-1/2011 and FRG0472-2017) and facilities provided by the Faculty of Food Science and Nutrition, Universiti Malaysia Sabah (UMS).

\section{References}

Abbey, B.W. and Ibeh, G.O. (1988). Functional properties of raw and heat processed cowpea (Vigna unguiculata) flour. Journal of Food Science, 53(6), 
$1775-1777$. 2621.1988.tb07840.x

Sulieman, A.A., Zhu, K.X., Hasssan, H.A., Obadi, M., Siddeg, A., Zhou, M.-H. (2019). Rheological and quality characteristics of composite gluten-free dough and biscuits supplemented with fermented and unfermented Agaricus bisporus polysaccharide flour. Food Chemistry, 271, 193-203. https:// doi.org/10.1016/j.foodchem.2018.07.189

Adeola, A.A. and Ohizua, E.R. (2018). Physical, chemical, and sensory properties of biscuits prepared from flour blends of unripe cooking banana, pigeon pea, and sweet potato. Food Science and Nutrition, 6 (3), 532-540. https://doi.org/10.1002/fsn3.590

Adeyeye, S.A.O. (2018). Quality evaluation and acceptability of cookies produced from rice (Oryza glaberrima) and soybeans (Glycine max) flour blends. Journal of Culinary Science and Technology, 18(1), 1-13. https:// doi.org/10.1080/15428052.2018.1502113

Abu, J.O., Muller, K. Duodu, K.G. and Minnaar, A. (2005). Functional properties of cowpea (Vigna unguiculata L) flours and pastes as affected by $\gamma$ irradiation. Food Chemistry, 93(1), 103-111. https:// doi.org/10.1016/j.foodchem.2004.09.010

Abulude, F.O., Ndamitso, M.M. and Yusuf, A. (2013). Food functional properties: A review. In Srivasta, Y. (Ed.). Advances in Food Science and Nutrition, p. 112. Nigeria: Science and Education Development Institute.

Adebowale, Y.A. and Adebowale, K.O. (2008). Evaluation of the gelation characteristics of mucuna bean flour and protein isolate. Electronic Journal of Environmental, Agricultural and Food Chemistry, 6 (8), 2243-2262.

Adebowale, K.O. and Lawal, O.S. (2004). Comparative study of the functional properties of bambara groundnut (Voandzeia subterranean), jack bean (Canavalia ensiformins) and mucuna bean (Mucuna pruriens) flours. Food Research International, 37(4), 355-365.

https://doi.org/10.1016/

j.foodres.2004.01.009

Adebowale, K.O. and Lawal, O.S. (2003). Foaming, gelation and electrophoretic concentrate. Food Chemistry, 83(2), 237-246. https://doi.org/10.1016/ S0308-8146(03)00086-4

Ahn, H.J., Kim, J.H. and Ng, P.K.W. (2005). Functional and thermal properties of wheat, barley, and soy flours and their blends treated with a microbial transglutaminase. Journal of Food Science, 70(6), c380-c386. https://doi.org/10.1111/j.13652621.2005.tb11433.x
Akapata, M.I. and Akubor, P.I. (1999). Chemical composition and selected functional properties of sweet orange (Citrus sinensis) seed flour. Plant Food Human and Nutrition, 54, 353-362. https:// doi.org/10.1023/A:1008153228280

Akintayo, E.T., Oshodi, A.A. and Esuoso, K.O. (1999). Protein extraction from Lima beans (Phaseolus lunatus) by different solutions. Journal of Science and Engineering and Technology, 6(2), 1687-1693.

Almazan A.M. (1990). Effect of cassava flour variety and concentration on bread loaf quality. Cereal Chemistry, 67, 97-99.

Alvarez-Jubete, L., Arendt, E.K. and Gallagher, E. (2010). Nutritive value of pseudocereals and their increasing use as functional gluten-free ingredients. Trends in Food Science and Technology, 21(2), 106113. https://doi.org/10.1016/j.tifs.2009.10.014

Awolu, O.O. (2018). Rheological evaluation of cocoyam -bambara groundnut-xanthan gum composite flour obtained from the optimization of its chemical composition and functional properties. Rheology: Open Access, 2(1), 1-8.

Awuni, V., Alhassan, M.W. and Amagloh, F.K. (2018). Orange-fleshed sweet potato (Ipomoea batatas) composite bread as a significant source of dietary vitamin A. Food Science and Nutrition, 6(1), 174179. https://doi.org/10.1002/fsn3.543

Baljeet, S.Y., Ritika, B.Y. and Roshan, L.Y. (2010). Studies on functional properties and incorporation of buckwheat flour for biscuit making. International Food Research Journal, 17, 1067-1076.

Berghofer, E. (2000). Brot als funktionales Lebensmittel. Getreide Mehl Brot, 54(3), 175-179.

Bugusu, B.A., Campanella, O. and Hamaker, B.R. (2001). Improvement of sorghum-wheat composite dough rheological properties and breadmaking quality through zein addition. Cereal Chemistry, 78 (1), 31-35. https://doi.org/10.1094/ CCHEM.2001.78.1.31

Chandra, S., Singh, S. and Kumari, D. (2014). Evaluation of functional properties of composite flours and sensorial attributes of composite flour biscuits. Journal of Food Science and Technology, 52, 3681-3688. https://doi.org/10.1007/s13197-014$1427-2$

Cheftel, J.C., Cuq, J.L. and Lorient, D. (1985). Amino acids, peptides, and proteins. Fennema, O.R. (Ed.), In Food Chemistry, p. 279-343. New York, USA: Marcel Dekker.

Chinma, C.E., Adewuyi, O. and Abu, J.O. (2009). Effect of germination on the chemical, functional and pasting properties of flour from brown and yellow 
varieties of tiger nut (Cyperus esculentus). Food Research International, 42,(8) 1004-1009. https:// doi.org/10.1016/j.foodres.2009.04.024

Cherry, J.P. and McWatters, K.H. (1981). Whippability and aeration. In Cherry J.P. (ed.), Protein functionality in foods. ACS Symposium Series, 147. p. 149-176. Washington D.C., USA: ACS. https:// doi.org/10.1021/bk-1981-0147.ch008

D’Appolonia, B.L. (1977). Rheology and baking studies of legume- wheat flour blends. Cereal Chemistry, 54, 53-63.

Del Rosario, R.R. and Flores, D.M. (1981). Functional properties of four types of mung bean flour. Journal of the Science of Food and Agriculture, 32(2), 175180. https://doi.org/10.1002/jsfa.2740320213

Dendy, D.A.V. (1993). Review of composite flour technology in the context of Tanzania presented at the Workshop Sorghum and Millets Marketing and Utilization, 3-5 May 1993. Arusha, Tanzania, Australia: Natural Resources Institute (NRI), University of Greenwich, UK.

Deshpande, S.S., Rangnekar, P.D., Sathe, S.K. and Salunkhe, D.K. (1983). Functional properties of wheat-bean composite flours. Journal of Food Science, 48(6), 1659-1662. https://doi.org/10.1111/ j.1365-2621.1983.tb05054.x

Du, S., Jiang, H., Yu, X. and Jane, J. (2014). Physicochemical and functional properties of whole legume flour. LWT - Food Science and Technology, 55(1), 308-313. https://doi.org/10.1016/ j.lwt.2013.06.001

Edun, A.A., Olatunde., G.O., Shittu., T.A. and Adeogun, A.I. (2019). Flour, dough and bread properties of wheat flour substituted with orange-fleshed sweet potato flour. Journal of Culinary Science and Technology, 17(3), 268-289. https:// doi.org/10.1080/15428052.2018.1436109

Emmanuel, K.O., Michael, A.I., Olajide, P.S. and Bakare, H.A. (2019). Quality attributes and storage stability of bread from wheat-tigernut composite flour. Journal of Culinary Science \& Technology, 17 (1), 1-14.

Fleming, S.E. and Sosulski, F.W. (1978). Microscopic evaluation of bread fortified with concentrated plant proteins. Cereal Chemistry, 55, 373-379.

Gbenga-Fabusiwa, F.J., Oladele, E.P., Oboh, G. Adefegha, S.A. and Oshodi. A.A. (2018). Nutritional properties, sensory qualities and glycaemic response of biscuits produced from pigeon pea-wheat composite flour. Journal of Food Biochemistry, 42 (4), e12505. https://doi.org/10.1111/jfbc.12505

Giami, S.Y. and Bekebain, D.A. (1992). Proximate composition and functional properties of raw and processed full-fat fluted pumpkin seed (Jelfairia occidentalis) flour. Journal of the Science of Food and Agriculture, 59(3), 321-325. https:// doi.org/10.1002/jsfa.2740590308

Giami, S.Y., Okonkwo, V.L. and Akusu, M.O. (1994). Chemical composition and functional properties of raw, heat-treated and partially proteolysed wild mango (Irvingia gabonensis) seed flour. Food Chemistry, 49(3), 237-243. https:// doi.org/10.1016/0308-8146(94)90166-X

Giami, S.Y. (1993). Effect of processing on the proximate composition and functional properties of cowpea (Vigna unguiculata) flour. Food Chemistry, 47(2), 153-158. https://doi.org/10.1016/0308-8146 (93) $90237-\mathrm{A}$

Graham, D.E. and Phillips, M.C. (1976). Foams. Academic Press, London. p. 237

Hailing, P.J. and Walstra, P. (1981). Protein stabilized foams. CRC Critical Review of Food Science and Nutrition, 15(2), 155-203. https:// doi.org/10.1080/10408398109527315

Hasmadi, M, Siti Faridah, A., Salwa, I., Patricia, M., Mansoor, A. H. and Ainnur Syafiqa, R. (2014). The effect of seaweed composite flour on the textural properties of dough and bread. Journal of Applied Phycology, 26, 1057-1062. https://doi.org/10.1007/ s10811-013-0082-8

Hasmadi, M., Jahurul, M.H.A. Mohamad Khairi, Z and $\mathrm{Yu}$, A.L. (2018). The influence of seaweed composite flour on the quality of muffin. Journal of Aquatic Food Product Technology, 27(5), 635-642. https://doi.org/10.1080/10498850.2018.1468841

Heywood, A.A., Myers, D.J., Bailey, T.B. and Johnson, L.A. (2002). Functional properties of low-fat soy flour produced by an extrusion-expelling system. Journal of American Oil Chemists' Society, 79(12), 1249-1253. https://doi.org/10.1007/s11746-002-0635 $-\mathrm{y}$

Hutton, C.W. and Campbell, A.M. (1981). Water and Fat Absorption. In Cherry, J.P. (Ed.). Protein functionality in foods, water and fat absorption. Vol. 147, p. 177-200. United States: Amercian Chemical Society. https://doi.org/10.1021/bk-1981-0147.ch009

Ikpeme-Emmanuel, C.A., Okoi, J. and Osuchukwu, N.C. (2009). Functional, antinutritional and sensory acceptability of taro and soybean based weaning food. African Journal of Food Science, 3(11), 372377.

Jafari, M., Koocheki, A. and Milani, E. (2018). Physicochemical and sensory properties of extruded sorghum-wheat composite bread. Journal of Food 
Measurement and Characterization, 12(1), 370-377. https://doi.org/10.1007/s11694-017-9649-4

Jitngarmkusol, S., Hongsuwankul, J. and Tananuwong, K. (2008). Chemical composition, functional properties and microstructure of defatted macademice flours. Food Chemistry, 110(1), 23-30. https://doi.org/10.1016/j.foodchem.2008.01.050

Jisha, S., Padmaja, G., Moorthy S.N. and Rajeshkumar, K. (2008). Pre-treatment effect on the nutritional and functional properties of selected cassava-based composite flours. Innovative Food Science and Emerging Technologies, 9(4), 587-592. https:// doi.org/10.1016/j.ifset.2008.06.003

Kaur, M. and Singh, N. (2005). Studies on functional, thermal and pasting properties of flours from different chickpea (Cicer arietinum L.) cultivars. Food Chemistry, 91(3), 403-411. https:// doi.org/10.1016/j.foodchem.2004.06.015

Kaur, M., Kaushal, P. and Sandhu, K.S. (2011). Studies on physicochemical and pasting properties of Taro (Colocasia esculenta L.) flour in comparison with a cereal, tuber and legume flour. Journal of Food Science and Technology, 50(1), 94-100. https:// doi.org/10.1007/s13197-010-0227-6

Kaushal, P., Kumar, V. and Sharma, H.K (2012). Comparative study of physicochemical, functional, anti-nutritional and pasting properties of taro (Colocasia esculenta), rice (Oryza sativa), pegion pea (Cajanus cajan) flour and their blends. $L W T$ Food Science and Technology, 48(1), 59-68. https:// doi.org/10.1016/j.1wt.2012.02.028

Khalil, A.H., Mansour, E.H. and Dawoud, F.M. (2000). Influence of malt on rheological and baking property of wheat-cassava composite flours. LWT - Food Science and Technology, 33(3), 159-164. https:// doi.org/10.1006/fstl.1999.0629

Kim, Y.S., Wiesenborn, D.P., Lorenzen, J.H. and Berglund, P. (1996). Suitability of edible bean and potato starch noodles. Cereal Chemistry, 73, 302308.

Kinsella, J.E. (1979). Functional properties of soy proteins. Journal of the American Oil Chemists' Society, 56(3), 242-258. https://doi.org/10.1007/ BF02671468

Köhn, C.R., Fontoura, A.M., Kempka, A.P., Demiate, I.M., Kubota, E.H. and Prestes, R.C. (2015). Assessment of different methods for determining the capacity of water absorption of ingredients and additives used in the meat industry. International Food Research Journal, 22(1), 356-362.

Kuntz Jr., I.D. (1971). Hydration of macromolecules III. Hydration of polypeptides. Journal of American
Chemist Society, 93, 514-515. https:// doi.org/10.1021/ja00731a036

Lagnika, C., Houssou, P.A.F., Dansou, V., Hotegni, A.B., Amoussa, A.M.O., Kpotouhedo, F.Y., Doko, S.A. and Lagnika, L. (2019). Physico-functional and sensory properties of flour and bread made from composite wheat-cassava. Pakistan Journal of Nutrition, 18(6), 538-547. https://doi.org/10.3923/ pjn.2019.538.547

Lin, M.J., Humbert, E.S. and Sosulski, F.W. (1974). Certain functional properties of sunflower meals. Journal of Food Science, 39(2), 368-370. https:// doi.org/10.1111/j.1365-2621.1974.tb02896.x

Maninder, K., Sandhu, K.S. and Singh, N. (2007). Comparative study of the functional, thermal and pasting properties of flours from different field pea (Pisum sativum L.) and pigeon pea (Cajanus cajan L.) cultivars. Food Chemistry, 104(1), 259-267. https://doi.org/10.1016/j.foodchem.2006.11.037

Marco, C. and Rosell, C.M. (2008). Functional and rheological properties of protein enriched gluten free composite flours. Journal of Food Engineering, 88 (1), 94-103. https://doi.org/10.1016/ j.jfoodeng.2008.01.018

Masood, S.B., Javaid, I., Ambreen, N., Hafiz, A.R.S., Mir, M.N.Q., Faiza, S. and Jahangir, M.A. (2011). Effect of flour blending on bread characteristics. International Journal of Food Safety, 13, 142-149.

Mansour, E.H., Dworschak, E., Pollhamer, Z., Gergely, A. and Hovari, J. (1999). Pumpkin and canola seed proteins and bread quality. Accreditation and Quality Assurance, 4(1-2), 59-70.

Maruatona, G.N., Duodu, K.G. and Minnaar, A. (2010). Physicochemical, nutritional and functional properties of marama bean flour. Food Chemistry, 121(2), 400-405. https://doi.org/10.1016/ j.foodchem.2009.12.054

McWatters, K.H. (1983). Compositional, physical, and sensory characteristics of okara processed from cowpea paste and Nigerian cowpea flour. Cereal Chemistry, 60, 333-336.

McWatters, K.H. and Chhinnan, M.S. (1985). Effect of hydration of cowpea meal on physical and sensory attributes of a traditional West African food. Journal of Food Science, 50(2), 444-446. https:// doi.org/10.1111/j.1365-2621.1985.tb13423.x

Mepba, H., Eboh, L. and Nwaojigwa, S.U. (2007). Chemical composition, functional and baking properties of wheat-plantain composite flours. African Journal Food, Agriculture, Nutrition and Development, 7, 1-22.

Mezgebo, K., Belachew, T. and Satheesh, N. (2018). 
Optimization of red teff flour, malted soybean flour, and papaya fruit powder blending ratios for better nutritional quality and sensory acceptability of porridge. Food Science and Nutrition, 6(4), 891-903. https://doi.org/10.1002/fsn3.624

Milán-Carrillo, J., Reyes-Moreno, C., Armienta-Rodelo, E., CaráH bez-Trejo, A. and Mora-Escobedo, R. (2000). Physicochemical and nutritional characteristics of extruded flours from fresh and hardened chickpeas (Cicer arietinum L). Lebensmittel-Wissenschaft und-Technologie, 33(2), 117-123. https://doi.org/10.1006/fstl.1999.0620

Mizubuti, I.Y., Júnior, O.B., De-Oliveira-Souza, L.W., Dos Santos Ferreira da Silva, R.S. and Ida, E.I. (2000). Functional properties of pigeon pea (Cajanus cajan (L.) flour and protein concentrate. Archivos. Latinoamericanos Nutricion, 50(3), 274-280.

Mohamed, S., Hamid, N.A. and Hamid, M.A. (1998). Food components affecting the oil absorption and crispness of fried batter. Journal of Science and Food Agriculture, 78(1), 39-45. https:// doi.org/10.1002/(SICI)1097-0010(199809)

78:1<39::AID-JSFA82>3.0.CO;2-G

Mohammed Nour, A.A., Mohamed, A.R., Adiamo, O.Q. and Babiker, E.E. (2018). Changes in protein nutritional quality as affected by processing of millet supplemented with Moringa seed flour. Journal of the Saudi Society of Agricultural Sciences, 17(3), 275-281. https://doi.org/10.1016/j.jssas.2016.05.006

Moure, A., Sineiro, J., Dominguez, H. and Parajo, J.C. (2006). Functionality of oilseed protein products. Food Research International, 39(9), 945-963. https://doi.org/10.1016/j.foodres.2006.07.002

Mwangwela, A.M., Waniska, R.D. and Minnaar, A. (2007). Effect of micronisation temperature $\left(130^{\circ} \mathrm{C}\right.$ and $170^{\circ} \mathrm{C}$ ) on functional properties of cowpea flour. Food Chemistry, 104(2), 650-657. https:// doi.org/10.1016/j.foodchem.2006.12.038

Nakai, S. (1983). Structure-function relationship of food proteins. Journal of Agriculture and Food Chemistry, 31, 676-683. https://doi.org/10.1021/ jf00118a001

Noorfarahzilah, M., Jau-Shya, L., Md Shaarani, S., Abu Bakar, M.F. and Mamat, H. (2014). Applications of composite flour in development of food products: A review. International Food Research Journal, 21(6), 2061-2074.

Nyembwe, P.M., de Kock, H.L. and Taylor, J.R.N. (2018). Potential of defatted marama flour-cassava starch composites to produce functional gluten-free bread-type dough. LWT, 92, 429-434. https:// doi.org/10.1016/j.lwt.2018.02.062
Obalolu, V.A. and Cole, A.H. (2000). Functional property of complementary blends of soybean and cowpea with malted or unmalted maize. Food Chemistry, 70(2), 147-153. https://doi.org/10.1016/ S0308-8146(99)00248-4

Okezie, B.O. and Bello, A.B. (1988). Physiochemical and functional properties of winged bean flour and isolated compared with soy Isolate. Journal of Food Science, 53(2), 400-430. https://doi.org/10.1111/ j.1365-2621.1988.tb07728.x

Oladele, A.K. and Aina, J.O. (2007). Chemical composition and functional properties of flour produced from two varieties of tigernut (Cyperus esculentus). African Journal of Biotechnology, 6(21), 2473-2476. https://doi.org/10.5897/AJB2007.0002391

Onimawo, I.A. and Asugo, S. (2004). Effects of germination on the nutrient content and functional properties of pigeon pea flour. Journal of Food Science and Technology-Mysore-, 41(20, 170-174.

Oshodi, A.A. and Ekperigin, M.M. (1989). Functional properties of pigeon pea (Cajanus cajan) flour. Food Chemistry, 34(3), 187-191. https:// doi.org/10.1016/0308-8146(89)90139-8

Padilla, F.C., Alvarez, M.T. and Alfaro, M.J. (1996). Functional properties of barinas nut flour compared to those of soybean. Food Chemistry, 57(2), 191196. https://doi.org/10.1016/0308-8146(95)00108-5

Panghal, A., Khatkar, B.S., Yadav, D.N. and Chhikara, N. (2018). Effect of finger millet on nutritional, rheological, and pasting profile of whole wheat flatbread (chapatti). Cereal Chemistry, 96(1), 86-94. https://doi.org/10.1002/cche.10111

Posner, E.S. and Hibbs, A.N. (1997). Wheat flour milling. St. Paul, MN: American Association of Cereal Chemists.

Rehman, S., Paterson, A., Hussain, S., Murtaza, M.A. and Mehmood, S. (2007). Influence of partial substitution of wheat flour with vetch (Lathyrus sativus L) flour on quality characteristics of doughnuts. LWT - Food Science and Technology, 40 (1), 73-82. https://doi.org/10.1016/j.lwt.2005.09.015

Rosell, C.M. and Marco, C. (2008). Rice. In Arendt, E.A. and Dal Bello, F. (Eds.), Gluten free cereal products and beverages. Oxford, UK: Elsevier. https://doi.org/10.1016/B978-012373739-7.50006-X

Sacchetti, G., Pinnavaia, G.G., Guidolin, E. and Dalla Rosa, M. (2004). Effects of extrusion temperature and feed composition on the functional, physical and sensory properties of chestnut and rice flour-based snack-like products. Food Research International, 37(5), 527-534. https://doi.org/10.1016/ 
j.foodres.2003.11.009

Sathe, S.K., Deshpande, S.S. and Salunkhe, D.K. (1982). Functional properties of winged bean protein. Journal of Food Science, 47(2), 503-506. https:// doi.org/10.1111/j.1365-2621.1982.tb10112.x

Sathe, S.K., Deshpande, S.S. and Salunkhe, D.K. (1981). Functional properties of black gram (Phaseolus mango, L) proteins. Lebensmittel-Wissenschaft und Technologie, 16, 69-74.

Senthil, A., Ravi, R., Bhat, K.K. and Seethalakshmi, M.K. (2002). Studies on the quality of fried snacks based on blends of wheat flour and soya flour. Food Quality and Preference, 13(5), 267-273. https:// doi.org/10.1016/S0950-3293(02)00023-X

Shih, F. and Daigle, K. (1999). Oil uptake properties of fried batters from rice flour. Journal of Agriculture and Food Chemistry, 47(4), 1611-1615. https:// doi.org/10.1021/jf980688n

Shrivastava, C. and Chakraborty, S. (2018). Bread from wheat flour partially replaced by fermented chickpea flour: Optimizing the formulation and fuzzy analysis of sensory data. LWT, 90, 215-223. https:// doi.org/10.1016/j.lwt.2017.12.019

Silaula, S.M., Lorimer, N.L., Zabik, M.E and Uebersax, M.A. (1989). Rheological and sensory characteristics of bread flour and whole wheat flour doughs and breads containing dry-roasted air-classified pinto and navy bean high-protein fractions. Cereal Chemistry, 66, 486-490.

Singh, N., Chawla, D. and Singh, J. (2004). Influence of acetic anhydride on physicochemical, morphological and thermal properties of corn and potato starch. Food Chemistry, 86(4), 601-608. https:// doi.org/10.1016/j.foodchem.2003.10.008

Singh, U. and Singh, B. (1991). Functional properties of sorghum - peanut composite flour. Cereal Chemistry, 68, 460-463.

Singh, R. Singh, G. and Chauhan, G.S. (1996). Effect of incorporation of defatted soya flour on the quality of biscuits. Journal of Food Science and Technology, 33, 355-357.

Sudha, M.L., Vetrimani, R. and Leelavathi, K. (2007). Influence of fibre from different cereals on the rheological characteristics of wheat flour dough and on biscuit quality. Food Chemistry, 100(4), 13651370 .

https://doi.org/10.1016/ j.foodchem.2005.12.013

Suresh, C., Samsher, S. and Durvesh, K. (2015). Evaluation of functional properties of composite flours and sensorial attributes of composite flour biscuits. Journal of Food Science and Technology, 52(6), 3681-3688.
Suresh, C. and Samsher., S. (2013). Assessment of functional properties of different flours. African Journal of Agricultural Research, 8(38), 4849-4852.

Tien, N.N.T., Duyen, T.T.M. and Hung, P.V. (2019). Substitution of wheat flour with highly enzymeresisted cassava starch and its effect on starch digestibility and quality of breads. Food Measurement and Characterization, 13, 1004-1010. https://doi.org/10.1007/s11694-018-0014-z

Traynham, T.L., Myers, D.J., Carriquiry, A.L. and Johnson, L.A. (2007). Evaluation of water holding capacity for wheat-soy flour blends. Journal of American Oil Chemists' Society, 84(2), 151-155. https://doi.org/10.1007/s11746-006-1018-0

Tufan, B., Sahin, S. and Sumnu, G. (2019). Utilization of legume flours in wafer sheets. Legume Science, 2(1), e12. https://doi.org/10.1002/leg3.12

Udensi, E.A., Eke, O. and Ukachukwu, S.N. (2001). Effect of traditional processing on the physicochemical properties of Mucuna cochinchinensis and Mucuna utilis flours. Journal of Food Agriculture and Environment, 1, 133-137.

Venktesh, A. and Prakash, V. (1993). Functional properties of the total proteins of sunflower (Helianthus annuus L.) seed effect of physical and chemical treatments. Journal of Agricultural and Food Chemistry, 41, 18-23. https://doi.org/10.1021/ jf00025a005

Wang, Y., Compaoré-Sérémé, D., Sawadogo-Lingani, H., Codaa, R., Katina, K., and Maina, N.H. (2019). Influence of dextran synthesized in situ on the rheological, technological and nutritional properties of whole grain pearl millet bread. Food Chemistry, 285, 221-230. https://doi.org/10.1016/ j.foodchem.2019.01.126

Wani, I.A., Sogi, D.S., Wani, A.A. and Gill, B.S. (2013). Physico-chemical and functional properties of flours from Indian kidney bean (Phaseolus vulgaris L.) cultivars. LWT - Food Science and Technology, 53 (1), 278-284. https://doi.org/10.1016/ j.lwt.2013.02.006

Wootton, M. and Bamunuarachchi, A. (1980). Application of differential scanning calorimetry to starch gelatinization. III. Effect of sucrose and sodium chloride. Starch, 32(4), 126-129. https:// doi.org/10.1002/star.19800320408

Yasui, T., Sasaki, T. and Matsuki, J. (1999). Milling and flour pasting properties of waxy endosperm mutant lines of bread wheat (Triticum aestivum L.). Journal of the Science of Food and Agriculture, 79(5), 687692. https://doi.org/10.1002/(SICI)1097-0010 (199904)79:5<687::AID-JSFA237>3.0.CO;2-X 
Yasumatsu, K., Sawada, K., Maritaka, S., Mikasi, M., Toda, J., Wada, T. and Ishi, K. (1972). Whipping and emulsifying properties of soybean products. Agricultural and Biological Chemistry, 36(5), 719727.

https://

doi.org/10.1080/00021369.1972.10860321

Yu, J., Ahmedna, M. and Goktepe, I. (2007). Peanut protein concentrate: Production and functional properties as affected by processing. Food Chemistry, 103 (1), 121-129. https:// doi.org/10.1016/j.foodchem.2006.08.012

Zhu, S.M., Lin, S.L., Ramaswamy, H.S., Yu, Y. and Zhang, Q.T. (2017). Enhancement of functional properties of rice bran proteins by high pressure treatment and their correlation with surface hydrophobicity. Food Bioprocess Technology, 10, 317-327 (2017). https://doi.org/10.1007/s11947-016 -1818-7 